\title{
Hematopoietic Stem Cell Transplantation in Thalassemia and Sickle Cell Anemia
}

\author{
Guido Lucarelli, Antonella Isgrò, Pietro Sodani, and Javid Gaziev \\ International Center for Transplantation in Thalassemia and Sickle Cell Anemia-Mediterranean \\ Institute of Hematology, Policlinic of the University of Rome Tor Vergata, Tor Vergata, Italy \\ Correspondence: g.lucarelli@fondazioneime.org
}

The globally widespread single-gene disorders $\beta$-thalassemia and sickle cell anemia (SCA) can only be cured by allogeneic hematopoietic stem cell transplantation (HSCT). HSCT treatment of thalassemia has substantially improved over the last two decades, with advancements in preventive strategies, control of transplant-related complications, and preparative regimens. A risk class-based transplantation approach results in disease-free survival probabilities of $90 \%, 84 \%$, and $78 \%$ for class 1,2 , and 3 thalassemia patients, respectively. Because of disease advancement, adult thalassemia patients have a higher risk for transplant-related toxicity and a $65 \%$ cure rate. Patients without matched donors could benefit from haploidentical mother-to-child transplantation. There is a high cure rate for children with SCA who receive HSCT following myeloablative conditioning protocols. Novel nonmyeloablative transplantation protocols could make HSCT available to adult SCA patients who were previously excluded from allogeneic stem cell transplantation.

$T^{\mathrm{h}}$ halassemia and sickle cell anemia (SCA) are the two most widely diffused hereditary hemoglobinopathies in the world. Thalassemia originated in Mediterranean, Middle Eastern, and Asian countries, and sickle cell anemia originated throughout African countries; both soon became globally spread because of spontaneous migration and migration imposed through slavery. Modern migration is currently causing both diseases, particularly SCA, to further invade European countries (see Williams 2012).

$\beta$-Thalassemia involves deficient or absent synthesis of the $\beta$-globin chains that constitute adult hemoglobin molecules. This genetic defect affects erythropoiesis through the entire process of maturation and proliferation of the erythron, with severe apoptosis due to accumulation of $\alpha 2$ chains in the erythroid precursors. Early death of the red blood cells continues in the blood circulation. Patients without transfusions experience an enormous expansion of the erythroid and severe hemolytic anemia.

In SCA, a single nucleotide substitutionvaline replacing glutamic acid at the sixth position of the $\beta$-globin chain of hemoglobin Aforms a pathological hemoglobin called hemoglobin S (HbS). The propensity of HbS polymerization causes the red blood cell structure to change to a stable sickle shape. Resulting episodic anemia and acute and chronic vaso-occlusion of small and large vessels in virtually all organs cause the polymorphic clinical features

Editors: David Weatherall, Alan N. Schechter, and David G. Nathan

Additional Perspectives on Hemoglobin and Its Diseases available at www.perspectivesinmedicine.org

Copyright (C) 2012 Cold Spring Harbor Laboratory Press; all rights reserved; doi: 10.1101/cshperspect.a011825

Cite this article as Cold Spring Harb Perspect Med 2012;2:a011825 
G. Lucarelli et al.

of the sickle cell disease. Intramedullary apoptosis is also present but moderate, never at the levels seen in thalassemia.

Many thalassemic patients need continuous red blood cell replacement through a sequential program of red blood cell transfusions; the SCA patient does not. Without transfusions, thalassemic patients have tremendous skeleton deformities, as well as hepatomegaly and splenomegaly due to expansion of the hematopoietic system with extramedullary hematopoiesis. The SCA patient can suffer from severe organ damage due to the sequence of $\mathrm{HbS}$ polymerization, formation of microemboli, adhesion to the intima of the vessels, and organ infarction. The pathogeneses and clinical aspects of thalassemia and sickle cell anemia are described in greater detail in other articles in this collection.

Because both thalassemia and SCA are genetic diseases in which the genetic defect is expressed in the hematopoietic system, they are both curable by allogeneic cellular gene therapy through hematopoietic stem cell transplantation. On the other hand, the separate pathogeneses of these two disorders explain why there must also be some differences between the transplantation procedures.

\section{HEMATOPOIETIC STEM CELL TRANSPLANTATION FOR THALASSEMIA}

\section{HSCT for Thalassemia: Risk Class Approach}

Allogeneic HSCT is used to treat hemoglobinopathies; after conditioning to overcome the immunological barrier, allogeneic stem cells are used as vectors to correct the basic genetic defect by replanting genes that are essential for normal hematopoiesis. Essentially, allogeneic HSCT treatment of these diseases can be considered as allogeneic stem cell gene therapy. It may some day be possible to use autologous stem cells transformed by the insertion of normal genes as vectors, but there is no indication that this approach will be a clinical option in the foreseeable future.

For treating diseases other than aplastic anemia, preparatory regimens for HSCT must achieve two objectives: elimination of the disor- dered marrow and establishment of a tolerant environment that will permit transplanted marrow to survive and thrive. There is a considerable body of experience with the use of busulfan (BU) and its derivatives for ablating marrow in patients undergoing HSCT for the treatment of non-malignant conditions (Parkman et al. 1978; Kapoor et al. 1981; Hobbs et al. 1986). Cyclophosphamide (CY) is a well-established agent for providing adequate immunosuppression for allogeneic engraftment (Thomas et al. 1972; Storb et al. 1991). The combination of BU and CY can eradicate thalassemia and facilitate sustained allogeneic engraftment. The two fundamental treatments in pretransplant preparation include eradication of the hematopoietic system by administration of a total dose of $14-16 \mathrm{mg} / \mathrm{kg}$ busulfan and suppression of the immune system by administration of a total dose of $200 \mathrm{mg} / \mathrm{kg}$ cyclophosphamide. Because of the overlap of the anti-proliferative activity of busulfan on the immune cell system and of cyclophosphamide on the hematopoietic stem cell system, the summed toxicity of these dosages of busulfan and cyclophosphamide reaches the tolerability threshold and cannot be increased.

When the allogeneic graft starts to proliferate in the recipient, an immunological graftversus-host reaction (graft-versus-host disease [GVHD]) may occur. GVHD can affect one or more organs to varying degrees, with the most frequently affected being the skin, gastrointestinal tract, and liver. GVHD is a serious complication of bone marrow transplantation and can be fatal; therefore, the prophylactic administration of cyclosporine (an immunosuppressive drug) is an important part of the pretransplant and posttransplant treatment. Three or four doses of methotrexate may also be given in addition to cyclosporine during the first $15 \mathrm{~d}$ after transplant.

The influence of pretransplant characteristics on the outcome of transplantation was analyzed in 161 patients $<17$ yr of age, who were all treated with exactly the same regimen (Storb et al. 1977; Lucarelli et al. 1990). Multivariate analysis showed that hepatomegaly of more than $2 \mathrm{~cm}$, portal fibrosis, and irregular chelation history were associated with a significantly 
HSCT in Thalassemia and Sickle Cell Anemia

reduced probability of survival. The quality of chelation was characterized as regular when deferoxamine therapy was initiated no later than 18 mo after the first transfusion and was administered subcutaneously for 8-10 h continuously for at least $5 \mathrm{~d} / \mathrm{wk}$. Any deviation from this regimen was defined as irregular chelation. On the basis of these risk factors, patients were categorized into three risk classes: Class 1 patients had none of these adverse risk factors, class 2 patients had one or two adverse risk factors, and class 3 patients had all three.

\section{HSCT from HLA-Matched Related Donors}

The results of transplants from HLA-matched related donors to class 1 , class 2 , and class 3 patients, obtained by our group, are reported in Table 1 (Lucarelli et al. 2008; Isgrò et al. 2010).

\section{Adult Patients}

Adult thalassemia patients have more advanced disease, with both disease- and treatment-related organ complications that are mainly due to prolonged exposure to iron overload. From November 1988 through September 1996, 107 $>16$-yr-old patients received transplants from matched donors at the Hospital of Pesaro. The median age for this population was $20 \mathrm{yr}$, with a range of 17-35 yr. The probabilities of survival, thalassemia-free survival, rejection mortality, and non-rejection mortality for this entire group were $66 \%, 62 \%, 4 \%$, and $37 \%$, respectively (Lucarelli et al. 1992, 1999).

From April 1997, 15 high-risk adult patients were prepared for transplantation with a reduced total dose of $90 \mathrm{mg} / \mathrm{kg}$ cyclophosphamide. The probabilities of survival, thalassemia-free survival, rejection mortality, and non-rejection mortality were $65 \%, 65 \%, 7 \%$, and $28 \%$, respectively (Gaziev et al. 2005).

\section{HSCT FROM ALTERNATIVE DONORS FOR THALASSEMIA}

A major obstacle to successful transplantation is the limited number of HLA-matched related donors within families. Approximately 60\% of patients lack a suitable family donor. Some of these patients could benefit from HSCT from matched unrelated donors. However, the chance of finding a matched unrelated donor is strongly dependent on the patient's ethnic background.

One study reported the outcome of bone marrow transplant (BMT) from matched unrelated donors who were prospectively selected

Table 1. Outcomes of hematopoietic cell transplantation from HLA-matched donors in cases of $\beta$-thalassemia

\begin{tabular}{lllll}
\hline Patients & Stem cell source & \multicolumn{1}{c}{ OS (\%) } & \multicolumn{1}{c}{ TFS (\%) } & \multicolumn{1}{c}{ Reference } \\
\hline$<17$ yr: 515 (class 1-2) & MSD /MRD & Class 1-2: 88\% & Class 1-2: 85\% & Lucarelli et al. 2008 \\
73 (class 3) & & Class 3: $87 \%$ & Class 3: 82\% & \\
Adult: 107 & & Adult: 66\% & Adult: 62\% & \\
68 & MUD & $79.3 \%$ & $40 \%$ & La Nasa et al. 2005a \\
33 & Cord blood & $100 \%$ & $79 \%$ & Locatelli et al. 2003 \\
70 & MSD $/$ MRD & $83 \%$ & $73 \%$ & Ghavamzadeh et al. 1997 \\
49 & Related: 28 & $89 \%$ (all patients) & Related: 82\% & Hongeng et al. 2006 \\
& Unrelated: 21 & & Unrelated: 71\% & \\
37 (class 1-2) & MSD & Class 1-2: $97 \%$ & Class 1-2: 89\% & Isgrò et al. 2010 \\
35 (class 3) & & Class 3: 87\% & Class 3: 80\% & \\
3 (class 1) & MSD & Class 1: NA & Class 1: NA & Sabloff et al. 2011 \\
75 (class 2) & & Class 2: $91 \%$ & Class 2: 88\% & \\
64 (class 3) & & Class 3: 64\% & Class 3: 62\% & \\
37 (NA) & & & \\
\hline
\end{tabular}

Abbreviations: OS, overall survival; TFR, thalassemia-free survival; NA, not available; MSD, matched sibling donor; MRD, matched-related donor; MUD, matched unrelated donor; SCD, sickle cell disease. 
G. Lucarelli et al.

using high-resolution molecular typing for HLA class I and class II loci; this study included 68 patients with thalassemia major who received $\mathrm{BU} / \mathrm{CY}$ or BU/FLU (fludarabine) and/or thiotepa (TT) as a conditioning regimen (La Nasa et al. 2005a). The study included 14 class 1,16 class 2, and 38 class 3 patients. Overall rates of survival, thalassemia-free survival, rejection, and transplant-related mortality (TRM) for the entire cohort were $79.3 \%, 65.8 \%, 14.4 \%$, and $20.7 \%$, respectively. The incidences of acute grade II-IV or grade III-IV GVHD were $40 \%$ and $17 \%$, respectively. Ten of 56 evaluable patients (18\%) developed chronic GVHD. Class 1 and class 2 patients had much better overall and disease-free survival $(96.7 \%$ and $80 \%$, respectively) than class 3 patients $(65.5 \%$ and $54.5 \%$, respectively). These investigators have also recently reported encouraging results in adult thalassemia patients who received bone marrow from matched unrelated donors, with rates of survival, thalassemia-free survival, TRM, and rejection of $70 \%, 70 \%, 30 \%$, and $4 \%$, respectively (La Nasa et al. 2005b). Similar results were reported in another study from Asia that included 21 children who received transplants from matched unrelated donors, as well as 28 patients who received transplants from matched related donors (Hongeng et al. 2006). The 2-yr thalassemia-free survival for patients who received transplants from matched unrelated donors was $71 \%$, compared with $82 \%$ for patients who received transplants from matched related donors.

Together, these data strongly suggest that improvements in donor selection and transplantation preparation have improved the safety of unrelated donor HSCT for thalassemia treatment. This appears to be a viable treatment option for selected patients when there is no suitable sibling donor.

\section{Results of Transplant from Haploidentical Donors}

Haploidentical transplantation may extend the use of this treatment option to the $50 \%-60 \%$ of patients who lack a suitably matched familial donor or an HLA-identical unrelated donor.
The presence of fetal cells in maternal blood and of maternal cells in fetal blood (fetomaternal microchimerism) suggests that immunological tolerance may exist between mother and offspring. The combination of a megadose of purified $\mathrm{CD} 4^{+}$cells and a highly immunomyeloablative conditioning regimen is crucial for overcoming the barrier of residual anti-donor cytotoxic T-lymphocyte precursors in Tcell-depleted mismatched transplants, and the addition of BMMCs (including NK cells, mesenchymal stem cells, and T-cells) to a T-celldepleted allograft may help engraftment and control GVHD. Recently, we reported the outcomes of 31 children with thalassemia who received transplants from haploidentical donors; 27 were from mothers, two from brothers, and two from fathers (Sodani et al. 2011). Eight patients received T-cell-depleted peripheral blood progenitor cells (CD34 ${ }^{+}$immunoselection) and $\mathrm{CD}^{+}{ }^{+}$and $\mathrm{CD} 19^{+}$-depleted bone marrow stem cells. Twenty-three patients received $\mathrm{CD}_{3}{ }^{+}$mobilized peripheral and bone marrow progenitor cells. Positive selection was performed using the CliniMACS procedure. The CD34 ${ }^{+}$grafts contained a median of 14.2 $\times 10^{6} / \mathrm{kg} \mathrm{CD} 34^{+}$cells (range, $5.4 \times 10^{6} / \mathrm{kg}$ to $\left.39 \times 10^{6} / \mathrm{kg}\right), 2 \times 10^{5} / \mathrm{kg} \mathrm{CD}^{+}$cells, and 0.19 $\times 10^{6} / \mathrm{kg} \mathrm{CD} 19^{+}$cells.

Between Day -59 and Day -11 before the transplantation, $60 \mathrm{mg} / \mathrm{kg}$ daily hydroxyurea and $3 \mathrm{mg} / \mathrm{kg}$ daily azathioprine were administered to eradicate marrow; and growth factors, granulocyte colony-stimulating factor, and erythropoietin were given twice weekly to maintain stem cell proliferation in the face of hypertransfusion, thereby facilitating the effect of the hydroxyurea. Fludarabine was administered at a dosage of $30 \mathrm{mg} / \mathrm{m}^{2}$ per day from Day -17 through Day -13 . Starting on Day -10 , the first 17 patients received 14 doses of $1 \mathrm{mg} / \mathrm{kg}$ oral busulfan (BU), three times daily over $4 \mathrm{~d}$ (total dose of $14 \mathrm{mg} / \mathrm{kg}$ over $4 \mathrm{~d}$ ). The following 14 patients received a corresponding dose of $\mathrm{BU}$, given intravenously, followed by intravenous $\mathrm{CY}$ at a dose of $50 \mathrm{mg} / \mathrm{kg}$ daily on each of the next $4 \mathrm{~d}$ (total dose of $200 \mathrm{mg} / \mathrm{kg}$ ); $10 \mathrm{mg} / \mathrm{kg}$ thiotepa and $12.5 \mathrm{mg} / \mathrm{kg}$ anti-thymocyte globulin (ATG-Fresenius S) were given daily from Days 
-5 to -2 . All patients received cyclosporine for GVHD prophylaxis for the first 2 mo posttransplantation.

All patients showed donor chimerism by Day 14 after HSCT. A granulocyte count of $>500 / \mathrm{mL}$ occurred after a median time of 13 d (range of 11-17). Seven patients rejected their grafts and survived with thalassemia; three patients showed early mixed chimerism, which was deemed persistent when observed at 14, 38, and 42 mo after the transplants. In 19 cases, the transplantation was successful with complete allogeneic reconstitution. Two patients died from transplantation-related causes; one died on Day +114 of Epstein-Barr virus cerebral lymphoma, and the other died on Day +92 from CMV pneumonia. All of the 22 cured children are no longer transfusion-dependent, with hemoglobin levels ranging from $10.3 \mathrm{~g} / \mathrm{dL}$ to $13.8 \mathrm{~g} / \mathrm{dL}$ (Sodani et al. 2010, 2011).

\section{Mixed Chimerism following HSCT for Thalassemia}

Mixed hematopoietic chimerism (MC) is an interesting phenomenon that sometimes occurs after HSCT for thalassemia. The incidence of MC was evaluated in 335 patients who received BMT from HLA-matched family donors for thalassemia; it was found to be $32.2 \%$ at 2 mo after transplant (Lucarelli et al. 2002). Of the 227 patients with complete donor chimerism, none rejected their grafts, whereas graft loss occurred in 35 of 108 patients (32.4\%) with $\mathrm{MC}$, indicating that $\mathrm{MC}$ is a risk factor for graft rejection in thalassemia patients. The percentage of residual host hematopoietic cells (RHCs) determined at 2 mo after transplant was predictive for graft rejection, with nearly all patients experiencing graft rejection when RHCs exceeded 25\%. The risk of graft rejection was only $13 \%$ in patients with $<10 \%$ RHCs and was $41 \%$ in patients with $10 \%-25 \%$ RHCs (Andreani et al. 1996, 2000). Unlike hematological malignancies in which residual host cells are predictive of relapse, patients with thalassemia can have lifelong stable mixed chimerism without rejection following transplantation. Of patients receiving BMT for thalassemia following myeloablative conditioning, $10 \%$ became persistent mixed chimeras and became transfusion independent, suggesting that once donor-host tolerance is established, a limited number of engrafted donor cells might be sufficient to provide significant improvement of disease phenotype in patients with thalassemia major.

We recently published a paper describing four long-term transplanted patients affected by hemoglobinopathies (Andreani et al. 2011a). These patients are characterized by the presence of few donor-engrafted nucleated cells, both in the peripheral blood and in the bone marrow; the majority of the erythrocytes were of donor origin. Moreover, by analyzing singularly picked-up burst-forming unit erythroid colonies, we showed that the proportion of donorderived erythroid precursors was equivalent to that observed in the mature nucleated cells, rather than that of the red blood cells. These results suggest that in patients characterized by the presence of PMC after HSCT, a selective advantage of the maturation of donor erythroid precursors might successfully contrast the problems associated with the recipient ineffective erythropoiesis (Andreani et al. 2011b).

\section{HEMATOPOIETIC STEM CELL TRANSPLANTATION FOR SICKLE CELL DISEASE}

Sickle cell disease (SCD) is associated with considerable morbidity and premature mortality, and HSCT is the only available therapy with curative intent. Outcomes of HSCT from matched sibling donors in pediatric patients have been excellent; however, the applicability of HSCT has been limited by lack of matched sibling donors and concerns regarding regimen-related toxicity. A reduced-intensity conditioning regimen has the potential to decrease regimenrelated morbidity and mortality. Improved understanding of the typical sequence of complications and the effects of treatments such as hydroxyurea and blood transfusions, as well as the impact of transplantation on organ damage, are likely to influence the timing and indications for transplantation. 
G. Lucarelli et al.

Following a demonstration of successful use of the combination of busulfan and cyclophosphamide in transplant for thalassemia, this protocol was applied to the transplant preparation for treating the other genetic hemoglobinopathy, sickle cell anemia, in 1986 (Vermylen et al. 1993). We first performed a transplant in a 16-yr-old African girl with SCA in 1993 (Giardini et al. 1993). Since then, there has been slow progress in stem cell transplantation for SCA, with only approximately 250 transplants performed to date worldwide, mainly reported in multicenter studies (Table 2). A major reason for this very conservative approach to using transplantation for SCA treatment is the absence of universally accepted indications for transplantation.

Transplantation has been offered primarily to younger patients with overt symptomatology. Most patients have received an HSCT following a preparative regimen with $14-16 \mathrm{mg} / \mathrm{kg}$ busulfan and $200 \mathrm{mg} / \mathrm{kg}$ cyclophosphamide. Additional immunosuppressive agents sometimes include equine antithymocyte globulin, rabbit antithymocyte globulin, antilymphocyte globulin, or total lymphoid irradiation. Cyclosporine A, alone or in combination with methylprednisolone or methotrexate, has been used for posttransplant graft-versus-host disease (GVHD) prophylaxis. The results of HSCT after myeloablative conditioning in children have been very encouraging, with disease-free survival in most studies of $\sim 85 \%$ and a TRM rate of $<10 \%$ (Table 2). The results of transplantation might be even better if HSCT were performed in children before the development of irreversible sickle vasculopathy-related complications (Vermylen et al. 1998; Lucarelli et al. 2011).
The experience of cord blood transplantation (CBT) has been limited in patients with SCD, with a total of 33 cases reported, twothirds of whom were in the related donor setting (Hsieh et al. 2011). The majority of related CBT have been 6/6 HLA-matched. In unrelated CBT, although more feasible for pediatric patients on the basis of the availability of $4 / 6$ HLA-matched cord blood unit, it appears to be associated with a great risk of graft rejection and GVHD. The largest study consisting of seven patients reported one death, an EFS of $43 \%$, five patients developed acute GVHD, and one patient chronic GVHD (Adamkiewicz et al. 2007). Moreover, CBT for adults is limited by the necessary total nucleated cell count per kilogram of body weight for engraftment to occur. At this time, transplant should be safely extended to patients with SCD using HLA identical donors, minimizing morbidity and mortality. The attainment of tolerance should allow extension of this curative approach to alternative donor sources.

\section{The Rome Experience in HSCT for Sickle Cell Disease}

A total of 11 SCA patients (Lucarelli et al. 2011) with a median age of $12 \mathrm{yr}$ (range of 2-16) received hematopoietic stem cell transplantations from HLA-identical, related donors, following a myeloablative conditioning regimen. Indications for transplantation were vaso-occlusive crisis, acute chest syndrome, avascular bone necrosis, chronic red blood cell transfusions, or hemorrhagic stroke. Five patients received preconditioning cytoreductive/immunosuppressive chemotherapy with hydroxyurea,

Table 2. Worldwide reported outcomes of myeloablative HSCT for sickle cell disease

\begin{tabular}{lcccccc}
\hline & $\begin{array}{c}n=50 \\
\text { (Vermylen } \\
\text { et al. 1998) }\end{array}$ & $\begin{array}{c}n=50 \\
\text { (Walters } \\
\text { et al. 2000) }\end{array}$ & $\begin{array}{c}n=11 \\
\text { (Locatelli } \\
\text { et al. 2003) }\end{array}$ & $\begin{array}{c}n=67 \\
\text { (Panepinto } \\
\text { et al. 2007) }\end{array}$ & $\begin{array}{c}n=87 \\
\text { (Bernaudin } \\
\text { et al. 2007) }\end{array}$ & $\begin{array}{c}n=11 \\
\text { (Lucarelli } \\
\text { et al. 2011) }\end{array}$ \\
\hline OS & $93 \%$ & $94 \%$ & $100 \%$ & $97 \%$ & $92 \%$ & $90 \%$ \\
DFS & $85 \%$ & $84 \%$ & $90 \%$ & $85 \%$ & $86 \%$ & $90 \%$ \\
Rejection & $10 \%$ & $10 \%$ & $9 \%$ & $13 \%$ & $5 \%$ & $10 \%$ \\
\hline
\end{tabular}

Abbreviations: OS, overall survival; DFS, disease-free survival. 
HSCT in Thalassemia and Sickle Cell Anemia

azathioprine, and fludarabine, as described elsewhere (Lucarelli et al. 2011). The remaining six patients were prepared for the transplant with busulfan, cyclophosphamide, and antithymocyte globulin. They received cyclosporine (CSA), low-dose methylprednisolone, and a short course of MTX as GVHD prophylaxis. All patients had sustained engraftment with donor chimerism of $100 \%$, except for one patient, who showed a persistent MC with $25 \%$ of donor cells. Starting 2 mo after transplantation, this patient showed a progressive decrease in donor chimerism until 25\%; she had stable mixed chimerism for more than $4 \mathrm{yr}$ without SCD-related events and was transfusion independent (Andreani et al. 2011a). All of the remaining patients had full donor chimerism in lymphoid and myeloid lineages. Seven patients developed grade 2 acute GVHD. The only patient who developed grade 3 GVHD had received a peripheral blood stem cell transplantation. All of the patients responded promptly to the steroid treatment given to control the acute GVHD. Four out of 11 patients had mild skin chronic GVHD that resolved completely following steroid use. Ten out of 11 patients survived without sickle cell disease, with Lansky/Karnofsky scores of 100. Median follow-up for survivors was 43 mo (range of 12-68 mo). One patient died 1 yr after transplantation in her home country; she was on tapering immunosuppressive treatment for chronic skin GVHD and died of pneumonia. The probabilities of survival, SCA-free survival, and transplant-related mortality 5 yr after transplant were 90\%, 90\%, and $10 \%$, respectively. After transplantation, none of the patients had complications typical of SCA, such as pains, stroke, or acute chest syndrome.

In sickle cell trait carriers, the use of G-CSF for peripheral stem cell mobilization may induce HbS polymerization and red blood cell sickling, and therefore transform a relatively stable steady state into a cascade of events resulting in a sickle cell crisis and, in severe cases, multi-organ dysfunction. We suggest the use of BM-derived HSCs versus G-CSF-mobilized HSCs especially when the donor is an HbS trait carrier.

\section{Mixed Chimerism following Myeloablative HSCT for SCA}

A subgroup of patients who undergo HSCT for SCA develop lifelong stable MC once donorhost tolerance is established (Andreani et al. 1996, 2000). Walters et al. (2001) observed stable MC in 13 out of 50 patients (26\%) who showed SCD-free survival for a median duration of $6.9 \mathrm{yr}$ (range of 4.2-13 yr). Of note, among these patients, five had mixed donor chimerism of $<75 \%$ (range of $11 \%-74 \%$ ), and none of them developed sickle cell-related complications during a follow-up period that ranged from 22 to $70.2 \mathrm{mo}$ (median of $36.3 \mathrm{mo}$ ).

Recently we reported the clinical course of a 6-yr-old girl who received a bone marrow transplant for sickle cell anemia (M Marziali, A Isgrò, D Fraboni, et al., in prep.). Four years after transplant, the patient showed stable mixed chimerism, as evidenced by a 39\% bone marrow (BM) level of donor-origin erythroid precursors, and $80 \%$ donor-origin red blood cells (RBCs) in peripheral blood $(\mathrm{PB})$. The patient received $\mathrm{BM}$ from her HLA-matched sister (Hb AA) after a conditioning regimen of $14 \mathrm{mg} / \mathrm{kg} \mathrm{BU}, 200 \mathrm{mg} /$ $\mathrm{kg} \mathrm{CY}$, and $10 \mathrm{mg} / \mathrm{kg}$ anti-thymocyte globulin (ATG). For prophylaxis against graft-versus-host disease (GVHD), the patient received cyclosporine (starting on Day -1 ) and a short course of methotrexate (MTX; $10 \mathrm{mg} / \mathrm{m}^{2}$ on posttransplant Days 1, 3, and 6 with folinic acid rescue). The course after allogeneic hematopoietic stem cell transplantation was uneventful, with rapid hematologic engraftment and no signs of acute or chronic GVHD. Molecular analysis of sorted cell subgroups revealed MC in nucleated cells, CD34 ${ }^{+}$progenitors, and RBCs in the $\mathrm{PB}$ and BM. Four years after transplantation, the level of donor NCs was 39\% in PB and 36\% at the $\mathrm{BM}$ level, in parallel to a very high proportion of donor-derived RBCs (80\%) in PB. The proportions of donor-derived RBCs and BFU-E at the BM level were $40 \%$ and $46 \%$, respectively, indicating the presence of quantitatively different red cell/nucleated cell chimerism. A possible explanation for the presence of a greater proportion of donor-derived RBC may be found in the improved survival of donor erythroid precursors, 
G. Lucarelli et al.

compared with the host counterparts that might be destroyed during ineffective erythropoiesis.

New Approach to Overcome Current Limitations: Reduced-Intensity Conditioning Regimens and Non-Myeloablative Regimens

A frequently encountered barrier to marrow transplantation for SCD treatment is lack of an HLA-identical donor. Another major limitation of current approaches is the high regimen-related toxicity that has stopped HSCT from being offered to patients older than $16 \mathrm{yr}$ of age or with advanced organ damage. Attempts to reduce the intensity of preparative regimens for SCD patients have been based on two approaches. One is to produce myeloablation, which requires donor marrow infusion for hematopoietic recovery. The second approach is to not eradicate host hematopoiesis, which would allow hematopoietic recovery even without donor stem cell infusion. Sustained engraftment and alleviation of clinical phenotype have been reported in SCD patients following a reduced-intensity conditioning regimen; However, HSCT using non-myeloablative regimens, although well tolerated, has generally not resulted in stable engraftment.

In a recent study, seven patients (18 yr or younger) with high-risk SCD were given a bone marrow graft from an HLA-matched sibling donor (Krishnamurti et al. 2008). The conditioning regimen consisted of a total dose of $6.4 \mathrm{mg} / \mathrm{kg}$ intravenous or $8 \mathrm{mg} / \mathrm{kg}$ oral $\mathrm{BU}$, a total dose of $175 \mathrm{mg} / \mathrm{m}^{2}$ FLU, a total dose of $130 \mathrm{mg} / \mathrm{kg}$ equine ATG, and TLI $500 \mathrm{cGy}$. Regimen-related toxicity was minimal. All but one patient had sustained engraftment. None of the patients developed greater than grade 2 acute GVHD or extensive chronic GVHD. Five out of seven patients developed MC. At a followup of $2-8.5 \mathrm{yr}$ after HSCT, all patients were alive, and six of the seven patients had no laboratory or clinical evidence of disease. These data are encouraging in terms of sustained engraftment with minimal toxicity. On the other hand, unfavorable outcomes have been reported from using a reduced-intensity conditioning regimen to treat adults with SCD (Van Beisen et al. 2000).
The rationale for lower-intensity conditioning regimens in hemoglobinopathies stems from historical experience indicating that stable MC is sufficient for cure (Nesci et al. 1998; Andreani et al. 2000). Thus, myeloablation may not be necessary for a successful outcome. In a retrospective multicenter series, Iannone et al. (2003) described a non-myeloablative HSCT approach in six pediatric patients with SCD and one with thalassemia. This very-low-intensity conditioning regimen consisted of minimal intensity treatment with FLU/2 Gy TBI. Two patients also received ATG. Regimen-related toxicity was minimal, but the treatment resulted in only transient donor engraftment in six of seven patients, suggesting that more intensive conditioning is required in individuals with pre-HSCT transfusion exposures.

More recently, a novel non-myeloablative conditioning regimen was reported to be successful in adults with SCD (Hsieh et al. 2009). Ten adults with a median age of 26 yr (range of 16-45 yr) and severe SCD underwent nonmyeloablative transplantation with PBSC from HLA-matched siblings. The conditioning regimen included a total dose of $1 \mathrm{mg} / \mathrm{kg}$ alemtuzumab on Days 7-3 and TBI of 300 cGy on Day 2. As GVHD prophylaxis, recipients received sirolimus initiated on Day 1 at a dose of $5 \mathrm{mg}$ every $4 \mathrm{~h}$ for three doses, then $5 \mathrm{mg}$ daily. Patients received $5.51 \times 10^{6}$ to $23.8 \times 10^{6} \mathrm{CD}^{2} 4^{+}$cells/ $\mathrm{kg}$. Nine of 10 patients had sustained engraftment, and one had rejection. No patient died. None of the patients had full donor chimerism in both lymphoid and myeloid lines. Acute or chronic GVHD did not develop in any patient. If studies using this method can show sustained mixed donor chimerism with low regimen-related toxicity, the paradigm that only severely affected patients with SCD be offered HSCT may shift, thus allowing more low-risk patients the option of cure without long-term morbidity.

\section{Sustained and Full Fetal Hemoglobin Production after Failure of Bone Marrow Transplant}

$\mathrm{HbF}$ increase has been reported in three transplanted SCD patients after graft failure (Ferster 
et al. 1995). Recent clinical observations performed by our group strongly support such novel approaches. The reactivation of HbF synthesis has been documented after bone marrow transplant (BMT) failure and autologous reconstitution in patients affected by $\beta$-hemoglobin disorders (Paciaroni et al. 2009).

It is possible that after myeloablative treatment, the vast majority of committed autologous erythroid progenitors were destroyed, and only autologous hematopoietic stem cells survived in marrow niches, restoring the ontological HbF regulation mechanisms (Bank 2006). Alternatively, the increased $\mathrm{HbF}$ may be due to a new status, induced by modulations and influences operating in the setting of the BMT (microenvironment and stage-specific cytokines), that reprograms globin-gene expression or selects "fetal clone" proliferation. These cases strongly support further research efforts to find ways to reverse the hemoglobin switch and induce $\mathrm{HbF}$ production in adults in order to treat $\beta$-hemoglobin disorders.

\section{CONCLUSIONS}

The only radical cure for homozygous thalassemia is to transplant bone marrow from an HLAidentical donor who is normal or heterozygous for thalassemia, which is capable of producing and maintaining a normal hemoglobin level in the recipient. All thalassemic patients, together with their parents and siblings, should be HLA typed for this purpose. When an HLA donor is available, we believe that bone marrow transplantation is mandatory in thalassemic patients of class 1 and 2, as well as for those of class 3 who are aged $<17 \mathrm{yr}$; adult patients should also be offered this possibility of a cure, but $30 \%$ will die of transplant-related mortality. Patients without matched family or unrelated donors could benefit from haploidentical mother-tochild transplantation, which has shown encouraging results, although it is still in the experimental phase.

A high cure rate has also been achieved by performing HSCT on children with SCA following current myeloablative conditioning protocols. Again, we think that HLA typing should be performed for all family members of an SCA child. If a genotypically identical sibling or phenotypically identical parent is identified, hematopoietic stem cell transplantation should be performed in all SCA patients aged $<17 \mathrm{yr}$, before the major complications of the disease affect the child. The novel non-myeloablative transplantation protocol for SCD patients could serve as a platform for its wide application, not only in adults but also in high-risk pediatric patients with SCD.

\section{REFERENCES}

* Reference is also in this collection.

Adamkiewicz TV, Szabolcs P, Haight A, Baker KS, Staba S, Kedar A, Chiange KY, Krishnamurti L, Boyer MW, Kurtzberg J, et al. 2007. Unrelated cord blood transplantation in children with sickle cell disease: Review of four-center experience. Pediatr Transplant 11: 641-644.

Andreani M, Manna M, Lucarelli G, Tonucci P, Agostinelli F, Ripalti M, Rapa S, Talevi N, Galimberti M, Nesci S. 1996. Persistence of mixed chimerism in patients transplanted for the treatment of thalassemia. Blood 87: 3494-3499.

Andreani M, Nesci S, Lucarelli G, Tonucci P, Rapa S, Angelucci E, Persini B, Agostinelli F, Donati M, Manna M. 2000. Long-term survival of ex-thalassemic patients with persistent mixed cjimerism after marrow transplantation. Bone Marrow Transplant 25: 401-404.

Andreani M, Testi M, Battarra M, Lucarelli G. 2011a. Split chimerism between nucleated and red blood cells after bone marrow transplantation for haemoglobinopathies. Chimerism 2: 21-22.

Andreani M, Testi M, Gaziev J, Condello R, Bontadini A, Tazzari PL, Ricci F, De Felice L, Agostini F, Fraboni D, et al. 2011b. Quantitatively different red cell/nucleated cell chimerism in patients with long-term, persistent hematopoietic mixed chimerism after bone marrow transplantation for thalassemia major or sickle cell disease. Haematologica 96: 128-133.

Bank A. 2006. Regulation of human fetal haemoglobin: New players, new complexities. Blood 107: 435-443.

Bernaudin F, Socie G, Kuentz M, Chevret S, Duval M, Bertrand Y, Vannier JP, Yakouben K, Thuret I, Bordigoni P, et al. 2007. Long-term results of related myeloablative stemcell transplantation to cure sickle cell disease. Blood 110: 2749-2756.

Ferster A, Corazza F, Vertongen F, Bujan W, Devalck C, Fondu P, Cochaux P, Lambermont M, Khaladji Z, Sariban E. 1995. Transplanted sickle-cell disease patients with autologous bone marrow recovery after graft failure develop increased levels of fetal haemoglobin which corrects disease severity. Brit J Haematol 90: 804-808.

Gaziev J, Sodani P, Polchi P, Andreani M, Lucarelli G. 2005. Bone marrow transplantation in adults with thalassemia. Treatment and long-term follow-up. Ann NY Acad Sci 1054: 196-205. 
G. Lucarelli et al.

Ghavamzadeh A, Nasseri P, Eshraghian MR, Jahani M, Baybordi I, Nateghi J, Khodabandeh A, Sadjadi AR, Mohyeddin M, Khademi Y. 1997. Prognostic factors in bone marrow transplantation for $\beta$ thalassemia major: Experiences from Iran. Bone Marrow Transplant 22: 1167-1169.

Giardini C, Galimberti M, Lucarelli G, Polchi P, Angelucci E, Baronciani F, Agostinelli F, Giorni G, Muretto P. 1993. Bone marrow transplantation in sickle-cell anemia in Pesaro. Bone Marrow Transplant 12: 122-123.

Hobbs JR, Hugh-Jones K, Shaw PJ, Downie CJC, Williamson S. 1986. Engraftment rates related to busulphan and cyclophosphamide dosages for displacement bone marrow transplants in fifty children. Bone Marrow Transplant 1: 201-208.

Hongeng S, Pakakasama S, Chuansumrit A, Sirachainan N, Kitpoka P, Udomsubpayakul U, Ungkanont A, Jootar S 2006. Outcomes of transplantation with related and unrelated-donor stem cells in children with severe thalassemia. Biol Blood Marrow Transplant 12: 683-687.

Hsieh MM, Kang EM, Fitzhugh CD, et al. 2009. Allogeneic hematopoietic stem-cell transplantation for sickle cell disease. N Engl J Med 361: 2309-2317.

Hsieh MM, Fitzhugh CD, Tisdale JF. 2011. Allogeneic hematopoietic stem cell transplantation for sickle cell disease: The time is now. Blood 118: 1197-1207.

Iannone R, Casella JF, Fuchs EJ, Chen AR, Jones RJ, Woolfrey A, Amylon M, Sullivan KM, Storb RF, Walters MC. 2003. Results of minimally toxic nonmyeloablative transplantation in patients with sicule cell anemia and $\beta$-thalassemia. Biol Blood Marrow Transplant 9: 519-528.

Isgrò A, Gaziev J, Sodani P, Lucarelli G. 2010. Progress in hematopoietic stem cell transplantation as allogeneic cellular gene therapy in thalassemia. Ann NYAcad Sci 1202. 149-154.

Kapoor N, Kirkpatrick D, Blaese RM, Oleske J, Hilgartner MH, Changanti RS, Good RA, O’Reilly RJ. 1981. Reconstitution of normal megakaryocytopoiesis and immunologic functions in Wiskott-Aldrich syndrome by marrow transplantation following myeloablation and immunosuppression with busulfan and cyclophosphamide. Blood 57: 692-696.

Krishnamurti L, Kharbanda S, Biernacki M, Zhang W, Baker KS, Wagner JE, Wu CJ. 2008. Stable long-term donor engraftment following reduced-intensity hematopoietic cell transplantation for sickle cell disease. Biol Blood Marrow Transplant 14: 1270-1278.

La Nasa G, Argiolu F, Giardini C, Pession A, Fagioli F, Caocci G, Vacca A, De Stefano P, Piras E, Ledda A, et al. 2005a. Unrelated bone marrow transplantation for $\beta$-thalassemia patients: The experience of the Italian Bone Marrow Tranplant Group. Ann NY Acad Sci 1054: 186-195.

La Nasa G, Caocci G, Argiolu F, Giardini C, Locatelli F, Vacca A, Ororfino MG, Piras E, Addari MC, Ledda A, et al. 2005b. Unrelated donor stem cell transplantation in adult patients with thalassemia. Bone Marrow Transplant 36: 971-975.

Locatelli F, Rocha V, Reed W, Bernaudin F, Ertem M, Grafakos S, Brichard B, Li X, Nagler A, Giorgiani G, et al. 2003. Related umbilical cord blood transplantation in patients with thalassemia and sickle cell disease. Blood 101: 2137-2143.
Lucarelli G, Gaziev J. 2008. Advances in the allogeneic transplantation for thalassemia. Blood Rev 22: 53-63.

Lucarelli G, Clift RA, Galimberti M, Angelucci E, Giardini C, Baronciani D, Polchi P, Andreani M, Gazlev D, Erer B, et al. 1990. Bone marrow transplantation in patients with thalassemia. N Engl J Med 322: 417-421.

Lucarelli G, Galimberti M, Polchi P, Angelucci E, Baronciani D, Durazzi SM, Giardini C, Albertini F, Clift RA. 1992. Bone marrow transplantation in adult thalassemia. Blood 80: $1603-1607$.

Lucarelli G, Clift RA, Galimberti M, Angelucci E, Giardini C, Baronciani D, Polchi P, Andreani M, Gazlev D, Erer B, et al. 1999. Bone marrow transplantation in adult thalassemic patients. Blood 93: 1164-1167.

Lucarelli G, Andreani M, Angelucci E. 2002. The cure of thalassemia by bone marrow transplantation. Blood Rev 16: $81-85$

Lucarelli G, Gaziev J, Isgrò A, Sodani P, Paciaroni K, Alfieri C, De Angelis G, Marziali M, Simone MD, Gallucci C, et al. 2011. Allogeneic cellular gene therapy in hemoglobinopathies_evaluation of hematopoietic SCT in sickle cell anemia. Bone Marrow Transplant doi: 10.1038/bmt.2011. 79.

Nesci S, Manna M, Lucarelli G, Tonucci P, Donati M, Buffi O, Agostinelli F, Andreani M. 1998. Mixed chimerism after bone marrow transplantation in thalassemia. Ann NY Acad Sci 850: 495-497.

Paciaroni K, Gallucci C, De Angelis G, Alfieri C, Roveda A, Lucarelli G. 2009. Sustained and full fetal hemoglobin production after failure of bone marrow transplant in a patient homozygous for $\beta^{0}$-thalassemia: A clinical remission despite genetic disease and transplant rejection. Am J Hematol 84: 372-373.

Panepinto JA, Walters MC, Carreras J, Marsh J, Bredeson CN, Gale RP, Hale GA, Horan J, Hows JM, Klein JP, et al. 2007. Matched-related donor transplantation for sickle cell disease: Report from the Center for International Blood and Transplant Research. Br J Haematol 137: 479-485.

Parkman R, Rappeport J, Geha R, Belli J, Cassady R, Levey R, Nathan DG, Rosen FS. 1978. Complete correction of the Wiskott-Aldrich syndrome by allogeneic bone-marrow transplantation. N Engl J Med 298: 921-927.

Sabloff M, Chandy M, Wang Z, Logan BR, Ghavamzadeh A, Li CK, Irfan SM, Bredeson CN, Cowan MJ, Gale RP, et al. 2011. HLA-matched sibling bone marrow transplantation for $\beta$-thalassemia major. Blood 117: 1745-1750.

Sodani P, Isgrò A, Gaziev J, Polchi P, Paciaroni K, Marziali M, Simone MD, Roveda A, Montuoro A, Alfieri C, et al. 2010. Purified T-depleted, CD34+ peripheral blood and bone marrow cell transplantation from haploidentical mother to child with thalassemia. Blood 115: 1296-1302 (Erratum in Blood 116: 1627).

Sodani P, Isgrò A, Gaziev J, Paciaroni K, Marziali M, Simone MD, Roveda A, De Angelis G, Gallucci C, Torelli F, et al. 2011. T cell-depleted HLA-haploidentical stem cell transplantation in thalassemia young patients. Pediatr Rep 22: e13.

Storb R, Champlin RE. 1991. Bone marrow transplantation for severe aplastic anemia. Bone Marrow Transplant 8: $69-72$. 
HSCT in Thalassemia and Sickle Cell Anemia

Storb R, Weiden PL, Graham TC, Lerner KG, Nelson N, Thomas ED. 1977. Hemopoietic grafts between DLAidentical canine littermates following dimethyl myleran. Evidence for resistance to grafts not associated with DLA and abrogated by antithymocyte serum. Transplantation 24: 349-357.

Thomas ED, Storb R, Fefer A, Slichter SJ, Bryant JI, Buckner CD, Neiman PE, Clift RA, Funk DD, Lerner KE. 1972. Aplastic anaemia treated by marrow transplantation. Lancet 1: 284-289.

van Beisen K, Bartholomew A, Stock W, Peace D, Devine S, Sher D, Sosman J, Chen YH, Koshy M, Hoffman R. 2000. Fludarabine-based conditioning regimen for allogeneic transplantation in adult with sickle cell disease. Bone Marrow Transplant 26: 445-449.

Vermylen C, Cornu G. 1993. Bone marrow transplantation in sickle cell anemia. Blood Rev 7: 1-3.

Vermylen C, Cornu G, Ferster A, Brichard B, Ninane J, Ferrant A, Zenebergh A, Maes P, Dhooge C, Benoit Y, et al.
1998. Haematopoietic stem cell transplantation for sickle cell anaemia: The first 50 patients transplanted in Belgium. Bone Marrow Transplant 22: 1-6.

Walters MC, Storb R, Patience M, Leisenring W, Taylor T, Sanders JE, Buchanan GE, Rogers ZR, Dinndorf P, Davies SC, et al. 2000. Impact of bone marrow transplantation for symptomatic sickle cell disease: An interim report. Multicenter investigation of bone marrow transplantation for sickle cell disease. Blood 95: 19181924.

Walters MC, Patience M, Leisenring W, Rogers ZR, Aquino VM, Buchanan GR, Roberts IA, Yeager AM, Hsu L, Adamkiewicz T, et al. 2001. Stable mixed hematopoietic chimerism after bone marrow transplantation for sickle cell anemia. Biol Blood Marrow Transplant 7: 665-673.

* Williams T. 2012. World distribution, population genetics, and burden of thalassemic and sickle cell syndromes. Cold Spring Harb Perspect Med doi: 10.1101/cshperspect.a011692. 


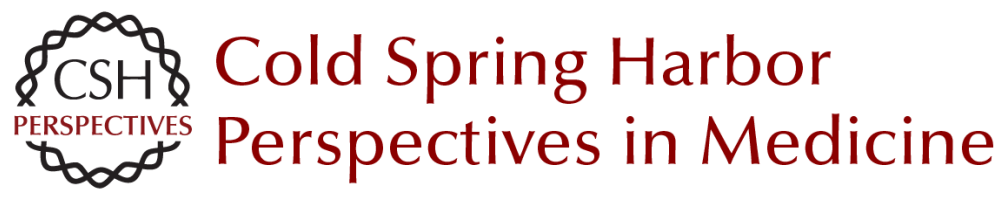

\section{Hematopoietic Stem Cell Transplantation in Thalassemia and Sickle Cell Anemia}

Guido Lucarelli, Antonella Isgrò, Pietro Sodani and Javid Gaziev

Cold Spring Harb Perspect Med 2012; doi: 10.1101/cshperspect.a011825 originally published online April 4,2012

\section{Subject Collection Hemoglobin and Its Diseases}

The Natural History of Sickle Cell Disease Graham R. Serjeant

Current Management of Sickle Cell Anemia Patrick T. McGann, Alecia C. Nero and Russell E. Ware

Cell-Free Hemoglobin and Its Scavenger Proteins: New Disease Models Leading the Way to Targeted Therapies Dominik J. Schaer and Paul W. Buehler

Clinical Manifestations of $\alpha$-Thalassemia Elliott P. Vichinsky

Erythroid Heme Biosynthesis and Its Disorders Harry A. Dailey and Peter N. Meissner

Hemoglobin Variants: Biochemical Properties and Clinical Correlates Christopher S. Thom, Claire F. Dickson, David A. Gell, et al.

The Prevention of Thalassemia Antonio Cao and Yuet Wai Kan

The Switch from Fetal to Adult Hemoglobin Vijay G. Sankaran and Stuart H. Orkin

\author{
Transcriptional Mechanisms Underlying \\ Hemoglobin Synthesis \\ Koichi R. Katsumura, Andrew W. DeVilbiss, \\ Nathaniel J. Pope, et al.
}

Iron Deficiency Anemia: A Common and Curable Disease Jeffery L. Miller

Management of the Thalassemias Nancy F. Olivieri and Gary M. Brittenham

The Molecular Basis of $\beta$-Thalassemia Swee Lay Thein

Erythropoiesis: Development and Differentiation Elaine Dzierzak and Sjaak Philipsen

Erythropoietin H. Franklin Bunn

Classification of the Disorders of Hemoglobin Bernard G. Forget and H. Franklin Bunn

The Molecular Basis of $\alpha$-Thalassemia Douglas R. Higgs

For additional articles in this collection, see http://perspectivesinmedicine.cshlp.org/cgi/collection/ 